RED HOT MAMA 


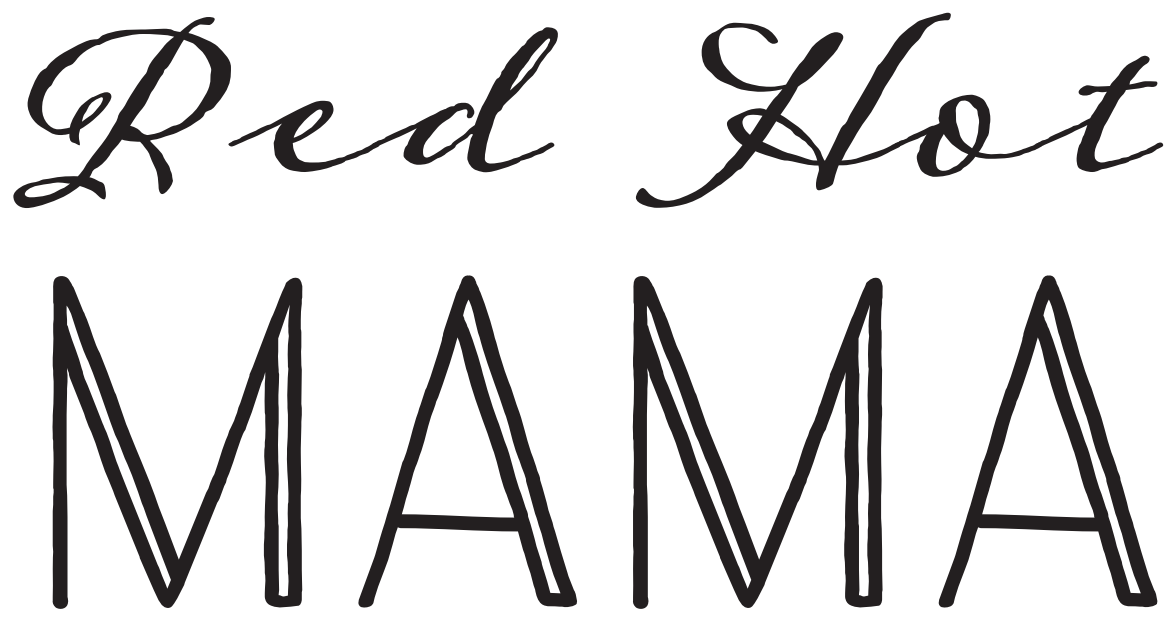

\section{THE LIFE OF SOPHIE TUCKER}

LAUREN REBECCA SKLAROFF

UNIVERSITY OF TEXAS PRESS 
Copyright (C) 2018 by Lauren Rebecca Sklaroff

All rights reserved

Printed in the United States of America

First edition, 2018

Requests for permission to reproduce material from

this work should be sent to:

Permissions

University of Texas Press

P.O. Box 7819

Austin, TX 78713-7819

utpress.utexas.edu/rp-form

The paper used in this book meets the minimum requirements of ANSI/NISO Z39.48-1992 (R1997) (Permanence of Paper). @)

Book design by Lindsay Starr

Typesetting by Integrated Composition Systems

Library of Congress Cataloging-in-Publication Data

Names: Sklaroff, Lauren Rebecca, author.

Title: Red hot mama : the life of Sophie Tucker / Lauren Rebecca Sklaroff.

Description: Austin : University of Texas Press, 2018. | Includes

bibliographical references and index.

Identifiers: LCCN 2017037715

Is B N 978-1-4773-1236-o (cloth : alk. paper)

IS B N 978-1-4773-1633-7 (library e-book)

IS B N 978-1-4773-1634-4 (nonlibrary e-book)

Subjects: LCSH: Tucker, Sophie, 1884-1966. | Singers-United States-

Biography.

Classification: LCC ML 420.T89 S55 2018 | D D 782.42164092 [в] —dc23

LC record available at https://lccn.loc.gov/2017037715

doi:10.756o/31236o 
For my mom, Ellen Sklaroff, with love 
This page intentionally left blank. 